\title{
Titik Temu Antara Falsafah dan Kehidupan Praktis
}

\author{
Meeting Point between Philosophy and Practical Life
}

IDRIS ZAKARIA* \& AHMAD SUNAWARI LONG ${ }^{1}$

\begin{abstract}
Philosophy and practical life are two different things. Philosophy is a theoretical in nature, while practical life covering all types of human actions and is bound by space, time and matter. Philosophy emphasizes analytical thinking, idealistic, holistic, comprehensive and practical. When all of these aspects compared, it looks different and has no relation. However, the reality of life illustrates that practical life mostly depends on philosophical commentaries and conclusion on any area of life. This article will prove the close relationship between these two things and its benefits to mankind.
\end{abstract}

Keywords: happiness, philosophy, philosophy of life, practical life

Jarang orang suka menghubungkan antara kehidupan praktis harian dengan 'falsafah'. Kehidupan praktis dikaitkan dengan tindakan sedar dan sukarela melakukan kerja-kerja harian dalam pelbagai bidang yang diceburi. Ia melibatkan penggunaan 'tulang-empat kerat' menjalan dan menyempurnakan kerja-kerja yang dipilih sama ada di pejabat, ladang, lebuh-raya, laut, kilang, rumah dan sebagainya. Tenaga fizikal sangat diperlukan. Kekuatan akliah digunakan juga tetapi tidak sama beratnya berbanding dengan kerja praktikal. Dari sudut hierakinya, kerjakerja akal yang datang dahulu dan kemudiannya disempurnakan oleh kaki, tangan dan anggota badan. Maksudnya kerja-kerja lahir itu adalah 'terjemahan' dari apa yang telah diputuskan oleh rumusan akal, maka kerja akal yang perlu tepat dan jelas. Jika tidak tepat, maka seluruh tindakan yang diambil akan menghadapi masalah. Kerja-kerja akal itu ada tempias falsafah di dalamnya, tetapi ia berlaku tanpa sedar atau dirancang. Namun dalam observasi umum, amat jarang orang merujuk kepada corak berfikir falsafah atau perbincangan bersifat falsafah. Apa yang sering ditanggapi umum ialah 'falsafah' itu adalah sesuatu ilmu yang ekslusif, bombastik, teoritis dan penuh dengan impian yang sukar untuk dicapai.

Apakah itu falsafah? Apakah skop atau ruang lingkup cakupan falsafah? Apakah fungsinya terhadap kehidupan? Di mana hubungkaitnya dengan kehidupan praktis seharian? Untungkah manusia dengan falsafah? Apakah ia satu keperluan? Persoalan-persoalan ini membawa kita untuk meninjau terlebih dahulu secara ringkas dan maksud falsafah terbabit.

\section{Apakah Falsafah?}

Plato (427-347 SM) merumuskan bahawa falsafah adalah pengetahuan tentang segala kewujudan, sementara muridnya Aristotle (384-322 SM) menyebut bahawa falsafah adalah usaha, aklyah menyelidik sebab dan asas segala benda, mengkaji hal yang beliau menamakannya sebagai metafizik yang meneliti asal wujud (being). Al-Farabi (870-950M), ahli Falsafah Islam berkata: "Falsafah ialah ilmu pengetahuan tentang alam yang wujud dan bertujuan menyelidik hakikatnya yang sebenarnya". Titus (1959: 8-9) mengemukakan beberapa pengertian tentang falsafah iaitu sikap tentang hidup dan alam semesta, satu kaedah pemikiran

\footnotetext{
${ }^{1}$ Idris Zakaria*(Corresponding author), Ph.D., Professor at Department of Theology and Philosophy, Faculty of Islamic Studies, Universiti Kebangsaan Malaysia, 43600 BANGI, Selangor, Malaysia. Email: aris@ukm.my; Ahmad Sunawari Long, Ph.D. Assoc. Prof. at Department of Theology and Philosophy, Faculty of Islamic Studies, Universiti Kebangsaan Malaysia, 43600 BANGI, Selangor, Malaysia. Email: aslong@ukm.my.
} 
reflektif dan penyelidikan akliah, satu peringkat (memahami) masalah dan satu peringkat teori atau sistem fikiran dalam usaha mencari kebenaran. Ibn Rushd (1126-1198) menjelaskan bahawa falsafah ialah penyelidikan tentang alam wujud dan memandangnya sebagai jalan untuk menemui Maha Pencipta segala ciptaan. Ibnu Tufayl (1110-1185) menegaskan falsafah berusaha mencari kebahagiaan dan kebenaran melalui pemikiran dan banyak lagi.

Meneliti pengertian-pengertia falsafah tersebut, pembaca akan segera dapat lihat bagai tiada hubungan dengan kehidupan praktis harian. Falsafah di satu pihak, kehidupan praktis di pihak yang lain. Sedangkan ahli falsafah menjelaskan bahawa falsafah mempunyai hubungan yang sangat rapat dengan kehidupan malah memberi pengaruh yang sangat berkesan dalam kehidupan. Socrates, guru Plato, direkodkan sebagai berkata "kehidupan yang tidak diperiksa tidak layak untuk dihayati (the unexamined life was not worth living)", membayangkan bahawa falsafah sebenarnya mendominasikan kehidupan manusia. Tanpa pemeriksaan falsafah sesuatu bentuk kehidupan tidak sesuai untuk dihayati atau menjadi pola kehidupan seseorang. Jadi falsafah itu penting dalam kehidupan.

\section{Hubungan Falsafah dan Kehidupan Praktis: Pandangan Ahli Falsafah}

Bagi membuktikan terdapat hubungan akrab antara falsafah dan kehidupan praktis, kita periksa dahulu sejarah dan pemikiran para intelektual dahulu itu apakah ada menggambarkan hubungan ini atau sebaliknya. Terdapat dua fasa pemikiran iaitu pemikiran sebelum Socrates dan pemikiran selepas Socrates. Falsafah sebelum Socrates digerakkan oleh Thales (625545SM), Anaximender (610-547 SM), Anaximenes (585-528 SM), Heraclitus (540-480 SM), Xenophanes (580-470 SM), Parmenides (540 SM), Zeno (334-262 SM), Pythagoras (580 SM-?), Empedocles (490-430SM), Anaxagoras (500-428 SM), Democritus (460-360 SM) dan lain-lain yang memberi fokus kepada alam fizikal ini. 'Segala kejadian' atau 'segala yang wujud' itu difokus kepada alam lahir ini yang juga dikaitkan dengan alam dewa-dewi atau segala macam Tuhan, yang misalnya dilagukan dalam syair pada waktu itu iaitu Homeros dan Hesiodos.

Fokus pemikiran berubah apabila tiba zaman Socrates (470-399SM) dan seterusnya Plato dan Aristotle. Pada mereka falsafah sudah ditukar pusat penelitian. Socrates tidak berminat lagi berfikir dan menyiasat tentang alam fizikal ini justeru katanya alam itu tidak berkomunikasi atau memberi respon terhadap manusia. Buku Plato Early Socrates Dialogues (1988) merakamkan dialog Socrates dengan sahabatnya Plato, Lysis, Ctesippus, Hippothales, Menexus dan lain-lain mengenai kehidupan melibatkan persoalan etika, ilmu pengetahuan, psikologi, kesihatan dan lain-lain yang semuanya berlegar tentang kehidupan menusia, bukan soal bukit, pokok, batu, angin, sungai dan sebagainya. Selain itu, Socrates menggunakan kaedah dialog, bertanya secara langsung orang yang beliau pilih tentang sesuatu isu atau makna sesuatu, dengan objektifnya bahawa ia boleh mengetahui tingkat fahaman orang yang ditanya dan tahu bagaimana fahamannya itu mempengaruhi kehidupannya.

Plato memberi perhatian terus kepada persoalan kehidupan ini. Dalam karya Plato, The Republic, umpamanya memberi perhatian terhadap rancangan dan strateginya untuk membentuk sebuah masyarakat dan negara yang terbaik, di mana ahli falsafah atau philosopherking dinobat dalam perancangannya sebagai pemimpin ideal. Tokoh impian ini menjalani kehidupan berilmu selama 35 tahun dan 15 tahun untuk mengumpul pengalaman sebagai pegawai tadbir. Kemudian beliau dibawa ke dalam dunia kepimpinan negara. Untuk kehidupan bahagia, Plato yakin pemimpin ini mampu membawa kesempurnaan dan kebahagian hidup itu.

Seorang lagi tokoh kenamaan Greek yang berusaha menawarkan kualiti hidup yang baik ialah Aristotle. Berkat 18 tahun dididik dan dibimbing Plato di Academi, Aristotle memilih untuk mengenal pasti mana satukah pentadbiran dan pengurusan yang baik melalui penyelidikan perlembagaan yang ada waktu itu. Beliau merumuskan bahawa pentadbiran, pengurusan serta kehidupan di Athen adalah lebih baik dari yang lain.

Ambil pula satu nama dari tradisi intelektual Islam, Ibnu Sina (980-1037M). Beliau juga dikesan menjadi pengikut Aristotle. Ibnu Sina yang banyak terlibat dalam pentadbiran di zamannya di bawah kepimpinan Majd al-Dawlah, Amir Shams al-Dawlah dan 'Ala al-Dawlah 
telah mengambil pendekatan realis untuk mencapai kehidupan yang baik. Ibnu Sina menekankan kepentingan hidup beragama dan kepatuhan kepada undang-undang sebagai antara syarat untuk membentuk kehidupan yang bahagia. Bukunya al-Syifa' umpamanya membawa idea dan semangat untuk mencapai kesempurnaan dalam kehidupan. Sementara buku al-Siyasah pula Ibnu Sina memberikan idea-idea bersifat manual tentang sebuah kehidupan yang teratur, terancang dan sistematik. Semuanya sebuah perancangan idealistik untuk hidup dan bahagia. al-Farabi (870-951M) tokoh pemikir sebelumnya juga telah cuba aplikasi falsafah dalam kehidupan praktis bernegara. Buku falsafah yang beliau tulis adalah respon langsung dari pergolakan dalam politik dan masyarakat zamannya. Beliau mencadangkan idea dan gagasan terbaik bagi mengubati penyakit negara dan masyarakat tersebut. Maka terhasillah bukunya Ara' Ahb al-Madinat al-Fadilah (Madinah Fadilah) Siyasah alMadaniyyah, Fusul al-Madani dan lain-lain. Wazler (1963: 19) menyatakan:

\begin{abstract}
Influenced by his political and social environment, al-Farabi has stressed the theoretical study of his society and its needs. He has written several treatises on politics, the most renowed of which is his 'model city'.
\end{abstract}

Penampilan beberapa tokoh kenamaan tersebut di atas membuktikan falsafah adalah suatu ilmu yang membahas pelbagai aspek permasalahan hidup manusia hari-hari (Konrad 2007: 16). Itulah falsafah yang sejati, ia tidak asing dari membahaskan masalah kehidupan. Ia berasas daripada kehidupan dan membantu memperbaiki kehidupan. Jenis falsafah yang dimiliki sesorang bergantung kepada situasi, cara berfikir, karakter dan latar belakang pendidikan seseorang. Hampir tiada bidang kehidupan yang tiada disentuh oleh falsafah. Oleh itu, menurut Immanuel Kant, kita seharusnya berfalsafah. Kita harus mampu membuat refleksi dan berfikir rasional bagi menghadapi realiti yang konkrit. Falsafah merupakan satu proses berfikir yang hidup dan bukannya satu ilmu yang mati. Falsafah adalah satu proses atau usaha mencari kebenaran secara terus-menerus, kerana itu ia adalah ilmu yang hidup.

Ada satu contoh yang benar-benar berlaku menggambarkan bagaimana falsafah memberi kejayaan kepada kehidupan sebuah keluarga Melayu di Pahang. Akhbar Utusan Malaysia 14 Mac 2009 melaporkan kegembiraan seorang suami Sahime Musa, 44, dan isterinya Jamaliah Aman, 43, setelah anak kembar mereka Muhamad Farid Farhan mendapat 11 A1, manakala Muhamad Fariz Fikri mendapat 10 A1. Kedua-duanya mencatatkan A1 dalam semua subjek yang diambil. Mereka berdua muncul antara pelajar terbaik SPM di negeri itu bagi tahun 2009. Apabila ditanya pihak akhbar apakah falsafah dan pendekatan yang dilakukan hingga anak kembarnya itu berjaya dalam peperiksaan SPM itu. Sahime menjelaskan "Saya pernah terbaca falsafah Confusius menyatakan bahawa kita boleh mengenal kebolehan anak kita sejak dari umur tiga tahun dan saya gunakan falsafah ini untuk mendidik anak saya." Confucius seorang ahli falsafah Cina yang banyak berbahas tentang pembangunan insan dan ini merupakan salah satu dari pemikirannya. Hasil ikatan terhadap falsafah itu, keluarga Melayu ini akhirnya menikmati kajayaan.

\title{
Fungsi Falsafah
}

Apabila falsafah jelas menyentuh hal kehidupan praktis, bagaimana fungsinya terhadap kehidupan itu? Biasanya tidak dinamakan kehidupan jika tidak berdepan dengan pelbagai masalah, samada masalah semasa atau masalah asasi kehidupan (Idris 1989: 1-2). Semua manusia berdepan dengan pelbagai masalah, maka mereka akan berusaha mencari penyelesaian. Sistem berfikir pun ligat mencari jawapan. Di sini falsafah menyumbang sesuatu yang bermakna. Pertama, ia memandu seseorang itu mengenal pasti pokok masalah terlebih dahulu, buat klasifisikasi dan seterusnya buka fikiran, berbincang, melihat pro dan kontra tiaptiap tanggapan. Kedua, falsafah menganjurkan berfikir dengan kritikal, logik, sistematik, teratur dan mendalam tanpa gangguan emosi, bias serta sentimental. Ketiga, membuka fikiran supaya isu yang dibahaskan itu luas mencakupi pelbagai bidang dan jurusan, dan akhirnya 'dipandu' menjurus kepada isu yang difokuskan. Keempat, kesimpulan atau rumusan dibuat diakhir 
proses pemikiran. Sebagai contoh, dialog antara Socrates dengan pelajar serta pengikutnya boleh dilihat dalam buku Plato, Early Socratic Dialogues.

Lebih fundamental lagi falsafah membantu manusia dalam hidupnya, memahami makna dan falsafah kehidupan. Ini sebenarnya permasalahan pokok dalam kehidupan tiap manusia. Manusia boleh 'turun' darjat menjadi haiwan atau 'naik' menjadi malaikat. Manakah kehidupan yang tinggi lagi mulia yang boleh menempatkan diri dari kehidupan yang lebih bermakna. Apakah yang perlu dilakukan untuk mencapai tahap tinggi yang dikejar? Falsafah seperti ini wajib difahami dan dimiliki oleh setiap orang dan guru untuk membantu membentuk falsafah hidup yang dilihat (Abdul Fatah 2009: 9). Ini titik temu yang sangat bermakna mengenai hubungan falsafah dan kehidupan manusia.

\section{Kebahagiaan Hidup}

Bercakap tentang kehidupan ini, objektif, matlamat dan tujuan hidup bagi kebanyakkan orang dibahas dengan sungguh-sungguh supaya rumusan yang didapati benar-benar menepati kehendak objektif, matlamat dan tujuan hidup tersebut. Di sini falsafah mencapai titik temu lagi. Apakah hasrat seseorang dalam hidup ini, apakah yang dimahukan? Kekayaan? Kebahagiaan? Kemasyhuran? Berjaya dalam kerjaya? Falsafah dari awal lagi sudah fokus terhadap isu ini, justeru ia adalah asas dan makna kehidupan itu sendiri. Setiap manusia perlu tepat dan jelas penetapan erti dan makna hidup ini jika tidak hidupnya tidak keruan. "Apakah yang aku mahu sebenarnya dalam hidup ini?"

Secara langsung falsafah tidak dapat menghasilkan kekayaan harta benda kepada seseorang. Kekayaan harta benda bukan dinilai kerana sifat fizikal yang dimilikinya sebaliknya melalui nilai intrinsiknya. Umpamanya, duit bukan dinilai kerana kertas, tetapi sumbangan yang diberikan untuk mencapai matlamat yang hendak dimiliki. Begitu juga falsafah, ia dinilai kerana nilai dalaman atau kebahagiaan yang diberikan kepada sesiapa yang dapat menikmatinya. Ia adalah kebahagiaan yang bersifat spiritual dan mental. Tema untuk mencapai kebahagiaan ini diketengahkan oleh ahli falsafah semenjak zaman pra-Socrates hingga ke hari ini. Antara tokoh yang berbuat demikian ialah Aristotle. Beliau mengetengahkan pendekatan berfikir terhadap sesuatu 'Hakikat Tertinggi (Realiti)' seseorang itu boleh mencapai kebahagiaan (eudaimonia). Berdasarkan perspektif falsafah, beliau cuba menghubungkan peranan manusia yang menggunakan akalnya dan yang bertindak sebagai manusia (ergon) untuk mencapai kebahagiaan yang tidak boleh dimiliki oleh makhluk yang lain (Ahmad Sunawari 2006).

Walaupun Aristotle mengutamakan kebahagiaan mental, namun keperluan fizikal tidak diketepikannya. Beliau menggariskan empat keperluan atau kebaikan asas sebagai prasyarat kebahagian. Pertama, kebaikan biologi seperti makanan, minuman, tempat tinggal dan pakaian yang sempurna bagi tujuan meneruskan kehidupan dan merasai kehidupan. Kedua, keperluan jasad seperti kesihatan dan kepuasan tubuh badan yang boleh memberikan keseronokan kepada manusia. Ketiga, keperluan luaran seperti kekayaan harta benda kerana ia merupakan antara faktor penentu menjamin kebaikan yang lain. Keempat, kebaikan roh kerana manusia dari segi sifat semula jadinya bersifat menyoal, berfikir dan mengetahui (rational animal) berdasarkan unsur tersebut (Barrow 1980: 17). Setelah memenuhi keperluan tersebut, manusia mesti merealisasikan dirinya untuk berfikir tentang kebahagiaan dan melakukan pemikiran terhadap Tuhan. Kehidupan yang terbaik untuk manusia ialah hidup berfalsafah, iaitu menggunakan akal dan bertindak sebagai manusia (ergon). Aristotle menjelaskan kebahagiaan yang ditunjukkan oleh falsafah seperti berikut:

Therefore, the activity of God, which surpasses all others in blessedness, must be contemplative; and human activities therefore that which is most akin to this must be most of the nature of happiness (Nichomachean Ethics, Bk.X. Chp. 18, 1178b21).

Jika diteliti, didapati setiap bentuk kehidupan praktis ini sukar untuk melepas diri dari falsafah. Di mana saja ada titik temu antara kedua-dua perkara tersebut. Kalau kita bercakap tentang baik-buruk tindakan kita atau kumpulan kita dalam sesuatu perkara, itu mudah 
menyentuh falsafah akhlak atau etika, yang juga sudah lama didiskusikan oleh ahli falsafah. Jika berbicara tentang kualiti kepimpinan, pengurusan negara, tanggungjawab rakyat dan lain-lain yang berkaitan, itu bermakna perbahasan sudah memasuki bidang falsafah sosial atau falsafah politik. Kalau menyebut tentang kejahatan, jenayah, hukuman terhadap pesalah dan sebagainya, ini bermakna perbincangan mengenai falsafah undang-undang sedang berjalan. Demikianlah hal-hal lain yang menyangkut misalnya agama, pembangunan, pendidikan dan sebagainya akan bertolak dari pada falsafah. Tanpa falsafah, bidang kehidupan tersebut akan hilang asas dan kawalan kebenarannya.

\section{Kedudukan Falsafah}

Jadi di manakah kedudukan atau status falsafah sebenarnya dalam kehidupan manusia itu? Sarwar (1976: 10) membuat kiasan bahawa falsafah ini bagai manusia juga yang berkeinginan mengawal semua tindakannnya, demikianlah falsafah satu-satu tamadun mendominasi semua perkara. Falsafah menjadi pemandu atau pengawal segala kegiatan. Lebih jelas, Sarwar mengambil kiasan kompas yang sangat besar fungsinya untuk kapal laut atau kapal terbang. Tanpa pertolongan kompas, kapal laut ataupun kapal terbang tidak boleh beroperasi dengan selamat:

The compass has nothing to do with the machinery which cause the ship to move in water, or an aeroplane in air, but without the guidance of a compass, or its equivalent, the ship or the aeroplane can never go right except by chance, but no chance can last for long. Similarly, the ship of science must be guided by workable philosophy...

Bagaimanakah manusia yang hidup tanpa dipandu atau dikawal oleh falsafah hidup (yang betul dan benar)? Jawapannya berbalik kepada apakah tabii dan objektif falsafah sebenarnya seperti yang telah disentuh pada awal makalah ini. Ibnu Tufail (1110-1185) menegaskan bahawa tujuan falsafah ialah untuk mencapai kebahagiaan dan kebenaran melalui pemikiran. Sementara tokoh sebelumnya al-Kindi (796-873) menyatakan bahawa falsafah sebagai ilmu termulai dan terbaik yang tidak wajar ditinggalkan oleh setiap orang yang berfikir kerana ilmu ini membicarakan tentang semua yang berguna dan cara memperolehinya serta cara menjauhi perkara yang merugikan (Shaharir 2000: 14). Walaupun setiap tokoh memberikan definisi yang berbeza menurut persepsi masing-masing tetapi rumusan akhir daripada tafsiran tersebut adalah kebenaran, kesempurnaan dan keadilan, sambil menolak nilai negatif yang merugikan manusia. Maksudnya kehidupan seseorang insan itu mudah tersasar dari landasan kehidupan yang baik dan berfaedah kepada dirinya sendiri.

Ada bukti tentang kehilangan arah tuju kehidupan yang berguna dan berfaedah ini. Utusan Malaysia 31hb Januari 2013 merekodkan kejadian seorang lelaki Cina, Lian Kim Wan yang sudah bertaraf nenek kepada 30 orang cucu, sanggup bergiat cergas dengan menjual bayi di Kajang, Selangor. Meskipun sebelum itu, dia telah dua kali dilepas dan dibebaskan daripada tiga tuduhan memperdagangkan tiga orang bayi yang berusia lima bulan. Namun beliau terus menjalankan kerja-kerja keji dan salah dari segi undang-undang negara. Hakim telah menjatuhkan hukuman penjara 14 tahun dan denda sebanyak RM30,000. Hakim Datuk Abdul Halim Abdullah dalam kenyataan penghakimannya menyatakan "Awak telah memusnahkan harapan bayi-bayi yang tidak berdosa. Wang adalah akar kepada kejahatan awak" Maksudnya, walaupun usia sudah tua, tetapi masih jahil untuk menentu dan menetapkan objektif dan falsafah hidup yang baik, berguna dan berfaedah. Wang, kekayaan dan kesenangan material menjadi matlamat dan bukan kebahagiaan dan ketenteraman jiwa. Maka, meringkuklah dalam penjara.

Apakah wang ringgit yang banyak menjadi faktor penentu kebahagiaan? Persoalan ini dibangkitkan di sini memandangkan ramai yang beranggapan wang adalah segala-segalanya. Wang adalah lambang kejayaan. Wang adalah bukti status yang baik dalam masyarakat. Dengan wang kata-kata kita didengari dan dengan wang juga banyak perkara boleh dilaksanakan. Apakah benar pandangan-pandangan ini? Cuba kita amati kenyataan-kenyataan berikut: 


\begin{abstract}
Kajian dan penyiasatan menunjukkan bahawa daripada orang-orang yang menganggap wang sebagai faktor yang penting untuk kebahagiaan, didapati hanya kebahagiaan kecil sahaja yang menganggap mereka bahagia. Sebaliknya orang-orang yang menggolongkan mereka berbahagia ialah orang-orang yang menganggap cinta, keluarga dan kebijaksanaan lebih penting daripada perhitungan wang yang banyak. Kebanyakkan orang tidak pernah belajar untuk menyelaraskan hidup dengan pendapatannya. Walaupun sebanyak mana wang yang mereka dapati. Mengurus dengan bijaksana wang kita perolehi lebih penting kepada ketenangan fikiran kita daripada sebanyak mana wang kita perolehi. (Gibson 1978).
\end{abstract}

\begin{abstract}
Money is good. Too much money is bad. 'Too much' is 'too much' when it is more than we need or more than we are capable of utilizing for the umpliment of humanity. Food is good. Too much food is damaging to the body and punishes the glutton with pain and illness. Light is good but too much will blind the eyes. Water is good. There could be no life for us without it, but too much will destroy us. Heat is good but too much will burn us. Any excuse in the use or activity of a good thing is temperance and therefore, evil can be avoided. (Bremer 1989: 366).
\end{abstract}

Perkara menarik dalam petikan di atas ialah wang bukanlah segala-segalanya dalam hidup. Memang betul wang adalah perlu. Dengan wang kita boleh membina kehidupan yang baik. Namun sikap dan pemikiran yang menganggap wang adalah segala-galanya, dan ia perlu dicari atau dicapai tanpa mengira wajar atau tidak, halal atau haram, maka orang itu telah tersalah falsafah hidupnya. Itu bukan lagi wang tetapi nafsu. Sifat nafsu ialah ia tidak pernah cukup sepanjang masa. Sesiapa yang sudah dikuasai nafsu, akan selamanya menjadi hamba kepada tamak haloba. Hidup tidak pernah reda dengan pemberian Tuhan. Tidak ada sikap berterima kasih apalagi bersyukur dengan rezeki yang ditentukan. Perkara kedua dalam petikan pertama itu ialah kebanyakan orang tidak pernah belajar untuk menyelaraskan hidup dengan pendapatannya. Apabila hilang penyelarasan antara gaji dengan tuntutan hidup, maka terbuka jalan untuk mencari tambahan tanpa berfikir kewajaran atau halal haram. Ini berlaku tanpa melihat kepada pangkat, gaji dan kedudukan. Gaji besar bukan jaminan mengelak rasuah. Pangkat besar, mungkin rasuah lagi besar. Sukar untuk kita lihat periuk besar, keraknya kecil!

\title{
Faedah Falsafah kepada Individu
}

Apakah faedah daripada kewujudan titik temu tersebut? Beberapa dimensi dapat dilihat hasil wujudnya titik-temu antara falsafah yang bersifat teoritikal dengan kehidupan konkrit manusia terutama kepada individu:

1. Falsafah dengan metod akal yang rasional akan membantu individu mencapai kepuasan dalam usahanya yang ingin mengetahui dan mencari jawapan mengenai sesuatu.

2. Falsafah akan meningkatkan tahap kematangan minda daripada peringkat rendah kepada kematangan. Pengetahuan yang akan diperolehi melalui penggunaan akal rasional membantu peningkatan ilmu dan sekaligus meningkatkan juga tahap kematangan individu.

3. Falsafah membina kemahiran dan kemantapan berfikir serta memperkenalkan metod berfikir yang sejahtera. Hal ini dapat dilihat apabila individu menggunakan metod yang sejahtera dalam berfikir, ia akan membawa individu tersebut kepada penguasaan kemahiran berfikir dan dapat menyelesaikan segala masalah dengan mudah dan cepat serta tepat.

4. Falsafah membantu individu menyelesaikan permasalahan kehidupan dengan sistematik dan pasti.

5. Falsafah menjadi senjata kepada individu untuk mempertahankan idea, pegangan dan kepercayaan (selain daripada jalan wahyu) daripada halangan dan kritikan. 
6. Falsafah mendorong individu mencapai matlamat yang dihajati dalam kehidupannya sama ada mencapai kejayaan, kebaikan, kesenangan dan kebahagiaan.

7. Falsafah menyediakan kemudahan yang mencukupi untuk individu berkembang maju ke hadapan menerusi pemikiran atau kreativiti, tingkah laku atau aktiviti dan menerusi model tokoh yang ideal dalam sejarah atau yang masih hidup supaya seseorang dapat mengukur kemajuannya dan memperbetulkan arah tujuannya.

8. Mengatur dan mengawal kehidupan individu dalam satu rangka kerja , tidak kira sama ada individu itu berpegang kuat pada mitos, adat istiadat, warisan, budaya tersendiri, undang-undang atau agama. Dalam semua perkara tersebut, terdapat satu rangka kerja, iaitu falsafah yang tersirat dalam sifat semula jadi dan itu yang penting untuk semua manusia. (Ensiklopedia Islam 1998).

Falsafah sememangnya tidak lari dalam memainkan peranan membentuk peribadi. Falsafah moral atau etika contohnya, merupakan suatu unsur yang membimbing kehidupan individu ke arah kehidupan yang penuh kebaikan dan menghindari diri seseorang dari keburukan. Falsafah dapat mempertingkatkan keyakinan individu kepada dirinya sendiri dan keyakinan kepada kekuasaan mutlak Allah s.w.t. bagi orang Islam. Tahap ini dapat dimiliki oleh individu yang mendalami dan menghayati konsep dan falsafah akhlak Islam, falsafah ini bermula dengan memberi pendidikan kejiwaan atau rohaniah kepada seseorang individu (Imran 2003).

\section{Faedah Falsafah kepada Negara}

Faedah juga boleh dikecapi dalam bentuk makro iaitu masyarakat dan negara. Contohnya, falsafah pendidikan negara. Selepas merdeka, negara Islam termasuk Malaysia, meneruskan sistem pendidikan yang telah bermula sejak zaman penjajahan. Namun, kurikulumnya telah diubahsuai selaras dengan hasrat dan semangat rakyat dan negara yang merdeka. Mata pelajaran pendidikan Islam telah dimasukkan ke dalam sistem tersebut. Apa yang benar dan berstruktur ialah pembentukan Falsafah Pendidikan Negara. Falsafah itu berbunyi:

Suatu usaha berterusan ke arah mengembangkan potensi individu secara menyeluruh dan bersepadu untuk mewujudkan insan yang seimbang dan harmoni dari segi intelek, emosi dan jasmani berdasarkan kepercayaan dan kepatuhan kepada Tuhan.

Penyataan ini daripada wawasan yang unggul mengenai pembangunan insan dalam Pendidikan. Falsafah Pendidikan Negara adalah terpancar daripada visi mengenai insan yang bukan dikonsepkan dalam bentuk warganegara biasa tetapi insan yang soleh, yang bertauhid kepada Allah yang Esa (Wan Mohd. Zahid 1998: 28-29). Agenda utama yang diketengahkan dalam Falsafah Pendidikan Negara (FPN) adalah berkait dengan psikologi insan. Penyataan FPN juga menyebut:

Pendidikan di Malaysia adalah satu usaha berterusan ke arah memperkembangkan lagi potensi kepercayaan dan kepatuhan kepada Tuhan. Usaha ini adalah bagi melahirkan rakyat Malaysia yang berilmu pengetahuan, berketerampilan, berakhlak mulia, bertanggungjawab dan berkeupayaan mencapai kesejahteraan diri serta memberi sumbangan terhadap keupayaan mencapai kesejahteraan diri serta memberi sumbangan terhadap keharmonian dan kemakmuran masyarakat dan Negara. (Kementerian Pendidikan Malaysia 1997: 42-43)

Tuntutan falsafah atau FPN ini sedang dilaksanakan. Generasi muda Malaysia membesar dan membangun dalam keadaan yang holistik dan seimbang, memenuhi kehendak intelek emosi dan jasmani yang disempurnakan melalui bidang akademik, vokasional, teknik dan agama. Bahasa juga pelbagai iaitu Bahasa Melayu, Inggeris, Arab, Cina, Tamil dan lain-lain. Sistem ini pula tidaklah bersifat serba sempurna. Ia diperiksa, dinilai dan dipinda menurut keperluan 
semasa. Jadi, falsafah tadi menjadi dasar (peletak asas) dan radar (pengawal dan pemerhati perjalanan sistem) sehingga objektif pendidikan negara tercapai.

Kesimpulannya, aktiviti falsafah yang diamalkan oleh Socrates iaitu berdialog dengan orang yang beliau pilih menggambarkan bahawa falsafah dari kehidupan bagai isi dan kuku. Aktiviti ini akhirnya diangkat menjadi program yang serius. Plato, Aristotle, St. Augustine, alFarabi, Ibnu Sina, Ibn Rushd, Ibnu Tufayl, Machiavelli, Iqbal dan sebagainya menulis buku yang berbicara tentang kehidupan dalam pelbagai bidang kehidupan. Oleh kerana falsafah bermatlamatkan kesempurnaan, keadilan dan kebahagiaan maka seorang insan, kumpulan masyarakat atau warga dalam sesebuah negara akan dibimbing dan dipandu ke arah matlamat tersebut jika mereka memiliki falsafah yang tepat dengan maksud kehidupan.

\section{References}

Abdul Fatah Hassan. 2001. Pengenalan Falsafah Pendidikan. Bentong: PTS Publication. Ahmad Sunawari Long. 2006. Sejarah Falsafah. Bangi: Universiti Kebangsaan Malaysia Aristotle. 1986. The Nicomachean Ethics. David Ross. (Transl.). Oxford: Oxford University Press. Barrow, R. 1980. Happines. Oxford: Martin Robertson.

Bremer, S. N. 1989. 366 Self motivating essays for students and adults. Singapore: Thinker Library Sdn. Bhd.

Ensiklopedia Islam. 1998. Leiden: E.J. Brill.

Gibson, J. E., 1978. Majalah Dian. Kota Bharu: Penerbit Dian Sdn. Bhd.

Idris Zakaria. 1989. Pemikiran Islam tentang kehidupan. Shah Alam: Marwilis Publisher and Distributors Sdn. Bhd.

Imran Affendy. 2003. Pemikiran akhlak Sheikh Abdurrahman Shiddiqi al-Banjari. Pekan Baru: Tetra Kencana.

Konrad Kebung. 2007. Filsafat itu indah. Jakarta: Prestasi Pustaka.

Plato. 1955. The Republic. Lee, H. D. P. (Trsl.). London: Penguin Classics.

Plato. 1988. Early Socrates dialogues. London: Penguin Classics

Sarwar, H. G. 1976. Philosophy of the Qur'an. Lahore: Mohd. Ashraf.

Shaharir Mohd. Zain. 2000. Pengenalan sejarah dan falsafah sains. Bangi: UKM

Titus, H. H. 1959. Living issues in philosophy: introductary text book. New York: New York Pub.

Utusan Malaysia. 14 March 2009 \& 31 January 2013.

Walzer, R. 1963. Greek into Arabic: essays on Islamic Philosophy. Oxford: Bruno Cassirer.

Wan Mohd. Zahid Mohd Nordin. 1998. Wawasan pendidikan. Kuala Lumpur: Cahaya Pantai Publishing (M) Sdn. Bhd. 